Review Article

\title{
Advances in Marine Geophysical Studies of the Indian Ocean: Contributions from India (2010-2015)
}

\author{
K S KRISHNA ${ }^{1, *}, K^{*}$ A KAMESH RAJU ${ }^{1}$, T RAMPRASAD ${ }^{1}$, A K CHAUBEY ${ }^{2}$, P DEWANGAN ${ }^{1}$ and \\ V YATHEESH ${ }^{1}$ \\ ${ }^{1}$ CSIR - National Institute of Oceanography, Dona Paula, Goa 403 004, India \\ ${ }^{2}$ CSIR - National Institute of Oceanography, Regional Centre, Lokhandwala Road, 4 Bungalows, Andheri \\ (West), Mumbai 400 053, India
}

(Received on 09 May 2016; Accepted on 30 May 2016)

\begin{abstract}
Indian scientists carrying marine geophysical research at different Earth Science institutions have made significant advances during the last six years (2012-2015) for understanding evolution of continental margins of India and deep sea regions. The investigations were mostly focused on continental margins of India encompassing deep-water regions, mid-ocean ridges, aseismic ridges and Andaman Sea including the back-arc basin. The studies were aimed at unraveling the tectonic and physical processes associated with evolution of the margins, ocean basins, volcanic structures, etc. In addition, industryrelated research for mapping of energy resources such as gas hydrates and hydrocarbons was also carried out in rifted basins on Eastern Continental Margin of India. The investigations were successfully carried out with integration of several geophysical datasets available at National Institute of Oceanography, India, National Geophysical Data Center, USA and petroleum industries, and by acquiring new geophysical data and geological sampling. In this report we describe major outcomes of the investigations focused on specific geological aspects of the Indian Ocean. Investigations carried out by individual works are also included in the bibliography.
\end{abstract}

Geophysical studies carried out over the Ninetyeast Ridge led to understand how the Kerguelen plume interacted with the spreading centers as well as with the lithosphere during emplacement of volcanic edifices, isostatic compensation mechanisms of the ridge and magma production rates in response to the Indian plate motion. The analyses of seismic data over the $85^{\circ} \mathrm{E}$ Ridge revealed the internal structure consisting of volcanic plug and several stratigraphic units such as lava-fed deltas and prograding clinoforms. The lava deltas along with intervening erosional surfaces and mass wasting on ridge flanks suggested that the ridge was built by both subaqueous and multiphase submarine volcanism during the late Cretaceous.

Study of seismic reflection data of the Eastern Continental Margin of India and adjacent deep-water region revealed two different phases of sediment deposition piled in the Bay of Bengal. The sediment distribution pattern, thickness and the bay architecture unveiled an occurrence of major change in sediment source from the peninsular India to the Bengal Basin at $\sim 23 \mathrm{Ma}$ as a result of uplift of Himalayas and onset of Asian monsoon system and this eventually led to the commencement and growth of the Bengal Fan. The gas hydrates studies in Krishna-Godavari (KG) offshore basin revealed that the hydrate distribution in the basin is controlled mainly by fault systems. The velocity analysis of sediment strata within the basin suggested occurrence of high concentration of gas hydrate close to the large-scale fault system. Thus, the fault system in KG Basin provides a conducive environment for the migration of methane, which upon entering the hydrate stability zone forms the fracture-filled gas hydrate deposits. Marine geophysical data of both the continental margins of India and western Andaman region were studied for extending the country's limit of the continental shelf beyond the Exclusive Economic Zone. The scientific and technical information extracted from the studies would serve its primary purpose of delineating the outer limits of India's continental shelf beyond 200 nautical miles.

The teleseismic studies of the back-arc basin, Andaman Sea revealed that the back-arc spreading fabric is undergoing readjustment to be in equilibrium with the current plate motions. A passive Ocean bottom seismometer (OBS) experiment in the back-arc basin recorded several events including teleseismic, microseismic and local events. Geological and geophysical

*Author for Correspondence: E-mail: krishna@nio.org 
studies over the Carlsberg and Central Indian Ridges have brought out finer scale segmentation of the ridge system and delineated zones of magmatic and sparsely magmatic sections of the ridges. The water column and deep-tow investigations carried out over the Carlsberg Ridge provided evidences for a prominent plume signatures emanating from a seafloor hydrothermal vent system.

A model for the early opening of the Arabian Sea for the period 88 to $56.4 \mathrm{Ma}$ is proposed with the consideration of the Gop and Laxmi Basin spreading centers as two arms of a triple junction and Narmada Rift on the Indian peninsula in the east as third arm of the triple junction. The reconstruction model did provide a new view on dispersals of Madagascar, Seychelles and India, during their early drift period, wherein the Laxmi Ridge and the Laccadive Plateau have been accommodated as intervening continental slivers.

Keywords: Indian Continental Margins; Rifted Basins; Andaman Back-Arc Basin; Bengal Fan; Ninetyeast Ridge; $8^{\circ}$ E Ridge; Carlsberg Ridge; Bengal Fan; Gas Hydrate Deposits

\section{Tectonics of Major Volcanic Structures of the Indian Ocean}

The Indian Ocean includes numerous elevated features such as linear volcanic ridges, mid-ocean ridges, seamount chains, oceanic plateaus, etc., which eventually led the Indian Ocean evolution very complex. The geophysical investigations using multibeam bathymetry, gravity, magnetic and seismic data over the Ninetyeast Ridge, $85^{\circ} \mathrm{E}$ Ridge and Afanasy Nikitin seamount have brought out new insights on evolution of these volcanic features, thereby contributed to the better understanding of structure and tectonics of the Indian Ocean. The observations and interpretations of each volcanic feature are comprehensively discussed below.

\section{Structure and Evolution of the $85^{\circ} \mathrm{E}$ Ridge and Afanasy Nikitin Seamount}

The $85^{\circ} \mathrm{E}$ Ridge is believed to extend from the Mahanadi Basin, off northeastern margin of India to the Afanasy Nikitin seamount in the Central Indian Basin. The ridge is associated with two contrasting gravity anomalies: negative anomaly over the north part (up to $5^{\circ} \mathrm{N}$ latitude), where the ridge structure is buried under thick Bengal Fan sediments and positive anomaly over the south part, where the structure is intermittently exposed above the seafloor. In contrast to this, the ridge consists of alternate streaks of positive and negative magnetic signatures distributed for asymmetrical extents. Ship-borne gravity and magnetic data were modeled earlier using seismic reflection results as constraints for determining the approximate age of the emplacement, isostatic mechanisms and temporal gravity fields of the ridge. During the last six years, attempts were made for understanding the emplacement of internal structure of the ridge and the Afanasy Nikitin seamount.

The gravity anomalies of the $85^{\circ} \mathrm{E}$ Ridge are reconstructed with possible crustal structures of different geological ages since the ridge formation. At the time of ridge emplacement, that is during the late Cretaceous the ridge was associated with a significant positive anomaly with a compensation generated by a regional flexure of the Moho boundary. By early Miocene the ridge was approximately covered by the post-collision sediments and led to alteration of the initial gravity anomaly to a small positive anomaly. At present, the ridge is buried by approximately $3 \mathrm{~km}$ thick Bengal Fan sediments on its crestal region and about $8 \mathrm{~km}$ thick pre- and postcollision sediments on the flanks. This geological setting had changed physical properties of the sediments and led to alter the minor positive gravity anomaly of early Miocene to the distinct negative gravity anomaly. The study shows that the negative gravity anomaly signature the $85^{\circ} \mathrm{E}$ Ridge has changed through time from its inception (positive anomaly) to present (negative anomaly).

Further both positive and negative magnetic anomalies of the $85^{\circ} \mathrm{E}$ Ridge are modeled using its seismic structure and geomagnetic polarity reversals. This shows that the ridge was formed during the period of rapid changes in Earth's magnetic field, earlier to that, the underlying oceanic crust was created in Cretaceous super-long normal polarity phase. The results further reveal that the positive and negative magnetic signatures of the ridge have been created, in general, by a relief of the ridge and polarity contrast between the ridge material and adjacent oceanic crust, 
respectively. On correlation of ridge's magnetization pattern to the geomagnetic polarity timescale, it is believed that the $85^{\circ} \mathrm{E}$ Ridge volcanism started at anomaly $33 \mathrm{r}$ time ( $~ 80 \mathrm{Ma})$ in Mahanadi Basin by a short-lived hotspot, thereafter the process continued towards south and finally ended at $\sim 55 \mathrm{Ma}$ in the vicinity of the Afanasy Nikitin seamount.

Analysis of high-quality long-streamer seismic reflection data of the $85^{\circ} \mathrm{E}$ Ridge unraveled the internal structure/ formations of the ridge and led to understand how the buried volcanic ridge originated and grew over a period of geological time. Seismic facies analysis reveals that the ridge internal structure consists of volcanic plug like feeders and several stratigraphic units including the packs of prograding clinoforms. The clinoform sequences are interpreted as volcanic successions leading to the formation of delta fronts. The structural architecture within the ridge and mass wasting on flanks of the ridge clearly suggest that the $85^{\circ} \mathrm{E}$ Ridge is a volcanic construct and was built by both subaqueous basal volcanism and subaerial multiphase (up to 4 phases with discrete time intervals) volcanism. The volcanic eruption began initially by punctuating the pre-existing ocean floor at $\sim 85 \mathrm{Ma}$ and may have led to subaqueous basal volcanism on uplifted basement rock. Then the ridge structure remained either above or close to the sea surface by keeping both accretion and syn-volcanic subsidence activities face-to-face at least for 2-3 Myr, which eventually facilitated formation of lenticular shaped carbonate sequence over apex of the ridge. During the early Miocene, the ridge became a subsurface feature and subsequently buried under rapidly deposited Bengal Fan sediments discharged from the Ganges and Brahmaputra river system. Therefore, it was concluded that the $85^{\circ} \mathrm{E}$ Ridge was constructed by a multiphase volcanism with short discrete time intervals during the late Cretaceous, and then submerged and buried under the thick fan sediments.

Combined analyses of new multibeam bathymetric, seismic reflection and geochronological data together with previously described magnetic data over the Afanasy Nikitin seamount (ANS), Central Indian Basin provided new insights into the growth of the ANS through time, and its relationship with the $85^{\circ} \mathrm{E}$ Ridge. The ANS comprises a main plateau, rising $1200 \mathrm{~m}$ above the surrounding ocean floor $(4800 \mathrm{~m})$, and secondary elevated seamount highs, two of which (lie at 1600 and $2050 \mathrm{~m}$ water depths) have the morphology of a guyot, suggesting that they were formed above or close to sea-level. An unbroken sequence of spreading anomalies 34 through $32 \mathrm{n} .1$ identified over the ANS reveal that the main plateau of the ANS was formed at 80-73 Ma, at around the same time as that of the underlying oceanic crust. The ${ }^{40} \mathrm{Ar} /{ }^{39} \mathrm{Ar}$ dates for two basalt samples dredged from the seamount highs were found to be consistent, within error, at $67 \mathrm{Ma}$. These results, together with published results of late Cretaceous to early Cenozoic Indian Ocean plate reconstructions, indicate that the Conrad Rise hot spot emplaced both the main plateau of the ANS and Conrad Rise (including the Marion Dufresne, $\mathrm{Ob}$ and Lena seamounts) at 80-73 Ma, close to the India-Antarctica Ridge system. Subsequently, the seamount highs were formed by late-stage volcanism c. 6-13 Myr after the main constructional phase of the seamount plateau. Flexural analysis indicates that the main plateau and seamount highs of the ANS are consistent with Airy-type isostatic compensation, which suggest emplacement of the entire seamount in a near spreading-center setting. This is contrary to the flexural compensation of the $85^{\circ} \mathrm{E}$ Ridge further north, which is interpreted as being emplaced in an intraplate setting, i.e., 25-35 Myr later than the underlying oceanic crust. Therefore, it is suggested that the ANS and the $85^{\circ} \mathrm{E}$ Ridge appear to be unrelated as they were formed by different mantle sources, and that the proximity of the southern end of the $85^{\circ} \mathrm{E}$ Ridge to the ANS is coincidental.

\section{Structure and Tectonics of the Ninetyeast Ridge and Magma Production Rate of the Kerguelen Hot Spot}

Magnetic and satellite gravity anomaly studies of both Central Indian and Wharton basins have provided precise locations of lineations from 19 through 34, fossil ridge segments that ceased at 65 and $42 \mathrm{Ma}$, and oceanic fracture zones. From trends of the Ninetyeast Ridge (NER) morphology and fracture zones fabric, it is found that the NER trends in $\mathrm{N} 10^{\circ} \mathrm{E}$ and obliquely crosses $\mathrm{N} 5^{\circ} \mathrm{E}$ oriented fracture zones. Thus the $89^{\circ} \mathrm{E} \mathrm{FZ}$ in the south borders the Ninetyeast Ridge on east side, while in the north the same FZ borders the ridge on west side. In both locations it exerts significant control of the morphology of the ridge. 
Interpretation of magnetic data revealed that the age of oceanic crust to the west of the $86^{\circ} \mathrm{E} \mathrm{FZ}$ increases towards north from early Cenozoic to late Cretaceous, while the crust to the east of the $90^{\circ} \mathrm{E}$ FZ increases its age in both north and south directions about middle Eocene fossil ridge segments. Contrasting to these trends, the crust between the FZs near NER shows a complex age succession together with fossil ridge segments of different ages (65 and $42 \mathrm{Ma}$ ). Newly determined radiometric ages of the NER reveal that the ridge was emplaced from 77 to $43 \mathrm{Ma}$ at a rate of $118 \pm 5 \mathrm{~km} / \mathrm{Myr}$. The age of the ridge decreases towards the south with remarkable linearity. The radiometric ages indicate that the ridge was formed at a rate of twice that of the formation of adjacent oceanic crust $(48-58 \mathrm{~km} /$ Myr). The Wharton spreading ridge segments, particularly in a strip between $86^{\circ} \mathrm{E} \mathrm{FZ}$ and $90^{\circ} \mathrm{E} \mathrm{FZ}$ and the Kerguelen hotspot were often in close proximity due to ridge jumps. Excess heat from the hotspot activity may have weakened the lithosphere and possibly led to southward ridge jumps at discrete ages. A large offset transform fault $\left(86^{\circ} \mathrm{E} \mathrm{TF}\right)$ once connected the India-Antarctica and Wharton ridges, appears to have become mechanically unstable whenever both the Kerguelen hotspot and ridgesegments are in close proximity. These conditions possibly have facilitated the ridge-segments to jump southward repetitively during the period $65-42 \mathrm{Ma}$. The difference in lengths of the NER $(\sim 3980 \mathrm{~km})$ and adjacent oceanic crust $(\sim 2000 \mathrm{~km})$ of the same age span is remarkable and requires a geodynamics explanation. Apparently southward ridge jumps lengthened the portion of Indian plate beneath the NER as the spreading ridge segments migrated southward to stay with a southward drifting of Kerguelen hotspot. Taking into account of spin axis deviation by no more than $\sim 5^{\circ}$ over the last $130 \mathrm{Myr}$, we provide an approximate estimate of $42 \mathrm{~mm} / \mathrm{yr}$ hotspot drift towards south-southwest direction for the formation of extra track of the NER.

Elastic plate thickness along Ninetyeast Ridge from $28^{\circ} \mathrm{S}$ to $8^{\circ} \mathrm{N}$ has been determined using flexural modeling and admittance analysis of 72 gravity and bathymetry profiles. The results suggest that, southern (south of $22^{\circ} \mathrm{S}$ ) and northern (north of $2^{\circ} \mathrm{N}$ ) part of the ridge are flexurally compensated with elastic plate thickness values of $>12$ and $>18 \mathrm{~km}$ respectively. Admittance analysis suggests that the central part $\left(20^{\circ} \mathrm{S}\right.$ to $\left.2^{\circ} \mathrm{N}\right)$ of the ridge has Airy type compensation with crustal thickness $15-20 \mathrm{~km}$. However, Te values derived using flexural modeling along profiles revealed that that central part of the ridge could be further divided into 1) south-central part $\left(18^{\circ} \mathrm{S}\right.$ to $\left.8^{\circ} \mathrm{S}\right)$ were the Te values constantly decreases from $20 \mathrm{~km}$ to $5 \mathrm{~km}$ and 2) north-central part $\left(8^{\circ} \mathrm{S}\right.$ to $\left.2^{\circ} \mathrm{N}\right)$ were Te values randomly varies between $2-25 \mathrm{~km}$.

Crustal structure of the Ninetyeast Ridge are interpreted using 2D gravity forward modeling of five east-west gravity profiles taking constraints from seismic results in view of its isostatic compensation. The results suggest that the crustal structure beneath Ninetyeast Ridge shows considerable variations. In the southern part at $\sim 26^{\circ} \mathrm{S}$, the ridge topography is compensated by down flexing of crustal layers $2 \mathrm{~B}$, $2 \mathrm{~A}$ and $3 \mathrm{~A}$ with amplitude of about $2.5-3 \mathrm{~km}$. In the south-central part $\left(\sim 13.5^{\circ} \mathrm{S}\right)$ suggests very thick $(20$ $\mathrm{km}$ ) oceanic crust beneath the along with underplated body of $\sim 10 \mathrm{~km}$ thick. In north-central part gravity models at $3^{\circ} \mathrm{N}$ suggest thickening of crust beneath the ridge topography, in contrast at $4^{\circ} \mathrm{N}$ the shows a different crustal structure, where the volcanic load is supported by down-flexing of crustal layers. These crust mantle configuration derived from the $2 \mathrm{D}$ forward modeling is in good agreement with the Te values obtained along the respective profiles. Based on the present results and available plate reconstruction models a plausible evolutionary model for the Ninetyeast Ridge is proposed. The southern part of the ridge was emplaced on a lithosphere of intermediate strength possibly along the edge of Indian plate whereas northern part was emplaced in an intraplate setting. The highly variable isostatic compensation mechanism in the central part of the ridge could be as a manifestation of the complex interaction of the Kerguelen hotspot and spreading ridge segments. The north-central part must have emplaced on a crust of highly variable age produced by multiple southward ridge jumps whereas the southcentral part on a crust of uniformly increasing age produced as a result of a major southward ridge jump.

Magma production rates along the NER track are computed using gravity-derived excess crustal thickness data. The production rates change between 2 and $15 \mathrm{~m}^{3} / \mathrm{s}$ over timescales of 3-16 Myr. Major variations in magma production rates are primarily associated with significant changes in the Indian plate 
velocity with low production phases linked to high plate velocity periods. The lowest magma production rate $\left(2 \mathrm{~m}^{3} / \mathrm{s}\right)$ at $62 \mathrm{Ma}$ is associated with the rapid northward drift of Indian plate under the influence of the Reunion mantle plume. The contemporaneous slowing of the African plate coincides with increase in magma production rate along the Walvis Ridge in the Atlantic Ocean. The present study suggests that variations in the Indian plate motion and frequent ridge jumps have a major role in controlling the magma production, particularly on long period cycles $(\sim 16$ Myr). Short-period variations ( $\sim 5 \mathrm{Myr})$ in magma productions may be associated with intrinsic changes in the plume, possibly due to the presence of solitary waves in the plume conduit.

New multichannel seismic reflection profiles imaged active faults along the entire length of the NER and show spatial changes in the style of deformation along the ridge. The northern NER $\left(0^{\circ} \mathrm{N}-\right.$ $5^{\circ} \mathrm{N}$ ) displays transpressional motion along WNWESE faults. In the central NER $\left(5^{\circ} \mathrm{S}-8^{\circ} \mathrm{S}\right)$, deformation on WNW-ESE-trending thrust faults implies nearly $\mathrm{N}-\mathrm{S}$ compression. An abrupt change in fault style occurs between $8^{\circ}$ and $11^{\circ} \mathrm{S}$, with modest, extension characterizing the southern NER $\left(11^{\circ} \mathrm{S}-27^{\circ} \mathrm{S}\right)$. In general active faulting is controlled by the reactivation of original, spreading-center formed, normal faults, implying that deformation is opportunistic and focused along existing zones of weakness, even when original fault trend is oblique to the direction of relative plate motion. Observed faulting can be interpreted as IndiaAustralia deformation in the northern NER and Capricorn-Australia deformation in the southern NER. The India-Capricorn boundary is directly adjacent to the northern NER and this juxtaposition combined with a different style of faulting to the east of the NER imply that the ridge is a tectonic boundary.

\section{Geophysical Studies of the Continental Margins of India and Adjoining Basins}

New seismic reflection data and other geophysical datasets over the western and eastern continental margins of India were analyzed for detailing the sediment deposition patterns, development of crustal blocks like Alleppey-Trivandrum Terrace Complex and delineation of outer limits of the continental shelf for the purpose of submission to UN Commission on the Limits of Continental Shelf (CLCS).
Sediment Dispersal Pattern in the Bay of Bengal - Evidence for Commencement of Bengal Fan Sedimentation

The sediment succession in the Bay of Bengal records signatures corresponding to India-Asia collision, regional climate, and erosional processes of the Himalayan orogeny and the Indian subcontinent. The Bengal Fan - world's largest submarine fan - has been long studied to understand the link between the Himalayan tectonics and Asian monsoon climate, but early phase information of the Himalaya erosion is not retrieved from the Indian Ocean due to lack of deep-core samples. Therefore, the missing corresponding signals hampered the understanding of coupled processes between tectonics, climate and erosion. Seismic reflection profiles and industrial drill wells from the western Bay of Bengal show two different modes of sediment deposition: initially Indian peninsular rivers discharged sediments to the ocean at a rate $\sim 20 \mathrm{~m} / \mathrm{m}$.y. until Oligocene-Miocene time ( $23 \mathrm{Ma})$ with the exception of two fairly-enhanced sediment pulses from 65 to 54 and again from 34 to $23 \mathrm{Ma}$; since $23 \mathrm{Ma}$ the Ganges and Brahmaputra rivers added huge volumes of sediments to the bay with variable rates range from 40 to $>1000 \mathrm{~m} / \mathrm{m}$.y. Using seismic stratigraphic technique we found a distinct increase in sediment discharge ( 140 m/m.y.) at $23 \mathrm{Ma}$ is an important age marker for the onset of Bengal Fan sedimentation as a coupled connection between the Himalayan tectonics and Asian climate. Further rise in sedimentation rate during the period 6.8 - 0.8 Ma is surprisingly not in agreement with the decrease in sediment rate reported at ODP Leg 116 sites in the distal Bengal Fan, but coincident with the change in monsoon intensity. Here we provide well constrained ages for the growth of the Bengal Fan, which can serve as benchmark for interactions between the Himalayan exhumation and Asian climate.

\section{Structure and Tectonics of the Alleppey- Trivandrum Terrace Complex (ATTC) on Western Margin of India}

The western continental margin of India is a passive continental margin evolved by rifting and subsequent drifting among India, Seychelles and Madagascar. A detailed understanding of the structure and tectonics of the continental margins and the associated ocean 
basins are significant as they can provide important constraints on conceptual evaluation of hydrocarbons. Under the continental margin programme, detailed geophysical investigations were carried out over the Alleppey-Trivandrum Terrace Complex (ATTC), which is an anomalous bathymetric protrusion in SW coast of India. This study was carried out to understand the crustal configuration of ATTC based on recently acquired bathymetry, multi-channel seismic reflection, gravity and magnetic data. The updated bathymetric contours of this region depicts that the ATTC consist of two contiguous terraces, the smaller Alleppey Terrace (between 300 and 400 $\mathrm{m}$ isobaths) in the north and the larger Trivandrum Terrace (between 1500 and $1900 \mathrm{~m}$ isobaths) in the south. The western boundary of the ATTC is defined by the Chain-Kairali Escarpment, which is a nearly $500 \mathrm{~km}$ long, steep linear escarpment. The multichannel seismic reflection data suggests a blockfaulted basement and presence of a nearly N-S trending wide basement high in the central part of the Trivandrum Terrace. The ATTC region is characterized by several prominent high amplitude magnetic and positive residual gravity anomalies superimposed over a broad negative free-air gravity anomaly. In the central part of the Trivandrum Terrace, the prominent gravity anomalies coincide with the wide basement high. Forward modeling of gravity and magnetic data constrained by seismic reflection information suggests that the crustal configuration of the ATTC region is comparable to a thinned continental crust containing volcanic bodies as intrusives/ extrusives.

\section{Gas Hydrate Studies in Krishna-Godavari Offshore Basin}

An integrated analysis of multi-channel seismic, highresolution sparker, sub-bottom profiler, swath bathymetry and coring/drilling datasets helped in understanding the gas hydrate system in the KrishnaGodavari (KG) offshore basin. The distribution of gas hydrates in KG offshore basin is controlled by fault systems formed due to shale/neo-tectonism. Large scale fault systems $(>5 \mathrm{~km}$ ) predominantly oriented in NNW-SSE direction are observed in the vicinity of NGHP-01-10 site, where $\sim 128 \mathrm{~m}$ of thick gas hydrate deposits is confirmed by drilling/coring. The increase in interval velocity from the baseline velocity of 1600 $\mathrm{m} / \mathrm{s}$ to $1750-1800 \mathrm{~m} / \mathrm{s}$ within the gas hydrate stability zone (GHSZ) is considered as a proxy for the gas hydrate occurrence, whereas the drop in interval velocity to $1400 \mathrm{~m} / \mathrm{s}$ suggests the presence of free gas below the GHSZ. The analysis of interval velocity derived from multi-channel seismic data suggests that the high concentration of gas hydrate occurs close to the large-scale fault system. Thus, the fault system provides a conducive environment for the migration of methane which upon entering the hydrate stability zone forms the fracture-filled gas hydrate deposits. Further, the deeper fluids migrating through these fault systems increase the geothermal gradient in the vicinity of the fault system. The detailed velocity model obtained from unified imaging as well as from the full waveform inversion supports the formation of gas hydrate within the fault system. A combination of diffusion and advection in fine grained sediments created a patchy Bottom Simulating Reflector (BSR) which has little to no apparent correlation with the overlying hydrate distribution. The attenuation model obtained from waveform inversion suggests that the hydrate-bearing sediments have low attenuation as compared to background marine sediment. The seismic quality factor $(\mathrm{Q})$, the inverse of seismic attenuation, is estimated independently using the peak frequency method which depends upon the variations of the peak frequency of the BSR spectrum as a function of travel time. The gas hydrate bearing sediments showed lower attenuation as compared to that of the background sediments. In contrast, active migration of free gas across the fault system leads to increase in seismic attenuation within the gas hydrate stability zone.

The fracture filled gas hydrate deposits show class IV amplitude variation with angle (AVA) pattern in contrast to class III AVA pattern predicted by the pore filled gas hydrate deposits in K-G basin. The anisotropic AVA analysis of BSR of a seismic profile in $\mathrm{KG}$ basin shows 5-30 \% gas hydrate concentration and the azimuth of fracture system with respect to the seismic profile is close to $45^{\circ}$. The estimated azimuth of the fracture is close to the dominant fracture direction as interpreted from $2 \mathrm{D}$ and $3 \mathrm{D}$ seismic data and the estimated gas hydrate concentration is close to that observed from the analysis of pressure cores and well logs.

The well logs of NGHP-Expedition-01 in KG Basin provided in-situ measurement of physical 
properties such as density and elastic velocities, which have been used to understand the interactions between sediment grains of unconsolidated marine sediments and hydrate. The conventional rock physics model assumes Hertz-Mindlin contact theory (no-slip across the grain contact), and then overestimated the observed shear wave velocity in KG offshore basin. Therefore, a modified rock physics model is proposed using Walton's smooth contact model (zero friction across the grain contact), which can predict the background shear wave velocity suggesting that the friction is almost negligible at the grain contact. The theory is extended for the gas hydrate bearing sediments using multi-grain contact (clay + quartz + hydrate), in which the effective modulus of sediment matrix is estimated by accounting for all possible contact combinations among the grains like quartzquartz (QQ), clay-clay (CC), clay-quartz (QC), quartz-hydrate $(\mathrm{QH})$, clay-hydrate $(\mathrm{CH})$, and hydrate-hydrate $(\mathrm{HH})$. The saturations estimated from the proposed theory using both $\mathrm{P}-$ and $\mathrm{S}$-wave velocities are comparable to each other and shows a good match with those estimated from resistivity logs and chloride anomalies.

High resolution sparker (HRS) data revealed that entire KG offshore basin seems to be associated with gas escape features like blanking zones, columnar type gas vents, fault controlled mud/shale diapirs, pockmarks etc., which are favorable for gas hydrate formation. The HRS records and bathymetry also show the evidence of slumping and sliding of the upper and mid-slope sediments in KG offshore basin, which resulted in mass transport deposits (MTD). Average thickness of MTDs varies with depth, i.e., in the upper slope, the thickness is about $45 \mathrm{~m}$, while in the lower slope it is about $60 \mathrm{~m}$, and in deeper offshore locations they attain a maximum thickness of about $90 \mathrm{~m}$. A direct indication for slumping and mass transportation of deposits is provided by the age reversal in ${ }^{14} \mathrm{CAMS}$ dates observed in a sediment core located in the midslope region. The presence of steep topographic gradients, high sedimentation rates, a regional fault system, diapirism, ûuid/gas movement, and neotectonic activity may have facilitated the slumping/ sliding of the upper slope sediments in the KG offshore basin.

\section{Geophysical Studies for the Limits of Continental Shelf}

Geological and geophysical investigations were carried out on both continental margins of India and adjacent deep-water regions to delineate margin architecture, structural features, nature of the crust, etc. A large amount of marine geophysical data (comprised of multi-channel seismic reflection, refraction, gravity, magnetic, and bathymetry) acquired on both the continental margins of India and western Andaman region were studied for delineation of outer limits of continental shelf of India for the purpose of extending the country's limit of the continental shelf beyond the Exclusive Economic Zone. The investigations carried out so far have provided a wealth of scientific information on nature of the seabed and sub-seabed in and off the Indian EEZ. The studies reveal two of the world's thickest accumulations of sediments on the seabed (the "Indus Fan" in the Arabian Sea and the "Bengal Fan" in the Bay of Bengal) derived from the Himalayas and a complex geological setting in the western offshore of Andaman-Nicobar islands. New underway geophysical data led to detail the morphometry of hitherto unmapped channels east of the Laxmi Ridge in the Arabian Sea. While the scientific and technical information gathered would serve its primary purpose of delineating the outer limits of India's continental shelf beyond 200 nautical miles, the surveys also have generated invaluable data that could form the cornerstone of the country's planned endeavors in the oceanic realm. Further detailed studies are expected to provide answers to longdebated questions such as history and geological evolution of seas and offshore sedimentary basins around us, origin and evolution of enigmatic features such as the $85^{\circ} \mathrm{E}$ Ridge in the Bay of Bengal, the Laxmi and Laccadive ridges in the Arabian Sea, the Gulf of Mannar, the offshore extent of the Deccan volcanics, the reasons for the association of gravity lows with structural highs in the Bay of Bengal, the development of the fans vis-a-vis the origin and growth of the Himalayas, etc. These studies also have opened a new vista in exploration for hydrocarbons in offshore areas of the extended continental shelf beyond 200 nautical miles. In addition, the data gathered is expected to provide specific insights related to such areas as marine ecosystems, unconventional energy, mineral resources, and hazards resulting from extreme events, such as earthquakes and tsunamis. 


\section{Geophysical Studies of the Deep-Water Regions}

The present day configuration of the continents, continental fragments and the deep ocean basins in the Indian Ocean was formed due to fragmentation and dispersal of the eastern sector of a continental assemblage, the Gondwanaland. Earlier studies have provided first order models to describe plate tectonic evolution of the Indian Ocean. However, these models were developed separately for different regions and their integration did provide inconsistent evolutionary models for the Indian Ocean. Therefore, a revisit is made for magnetic anomaly identifications and evolution of the Indian Ocean in a common framework using the most reliable geomagnetic timescale to date and modern tools for better-constrained magnetic anomaly identifications and finite rotation parameter estimations. A detailed magnetic study in the Wharton Basin constrained the Indian-Australian relative motion between 83 and $38 \mathrm{Ma}$, thereby plate reconstruction models were developed to describe the stage-by-stage evolution of the basin. These reconstructions were further used to model the structure and age of the subducted northern Wharton Basin and to constrain the thickness, buoyancy, and rheology of the plate subducting under Indonesia. Regional stress field around India and offshore Sumatra was modeled for three time slices, the Late Oligocene (33 Ma), the early Miocene (20 Ma) and the present. The results show that, at $33 \mathrm{Ma}$, maximum horizontal compressive stress were straddled India's west coast, while India's east and the Wharton Basin were characterized by relatively low intra-plate stresses. But, between $20 \mathrm{Ma}$ and the present, the model suggests the development of an arcuate belt with anomalously high intra-plate stress that stretches from India to the Wharton Basin, resulting a compressive tectonic regime favouring folding and inversion northeast of the Godavari graben on India's east coast. Therefore, the model provides an explanation for the peculiar clustering of large earthquakes in the northern Wharton Basin, including the intra-plate magnitude 8.6 and 8.2 events in April 2012, the largest oceanic intra-plate earthquake in the instrumental record.

A plausible model for the early opening of the Arabian Sea for the period 88 and $56.4 \mathrm{Ma}$ is provided, using the constraints of recently mapped regional scale tectonic elements from the deep ocean basins off west coast of India. It is considered that the Gop and Laxmi Basin spreading centers obviously represent the two arms of a triple junction and Narmada Rift on the Indian peninsula in the east is considered to represent the third arm of this triple junction, which is referred as the Gop-Narmada-Laxmi triple junction. The reconstruction model did provide a new view about the dispersals of Madagascar, Seychelles and India, during their early drift period, wherein the Laxmi Ridge and the Laccadive Plateau have been accommodated as intervening continental slivers.

A tectonic model reconciling evidence for the collisions between India, Eurasia and intra-oceanic arcs of the central-eastern Tethys, assimilating geological information from southern Eurasian margin and the geophysical information from the Indian Ocean is prepared. Geological evidences from the collision zone reveal an age of initial arc-continent collision by $\sim 52 \mathrm{Ma}$, followed by the initial continentcontinent collision between India and Eurasia by $\sim 44$ $\pm 2 \mathrm{Ma}$. This timing is supported by marine geophysical data, where the spreading centers in the Indian Ocean record a drastic decline in seafloor spreading rates and changes in spreading directions first at $\sim 52 \mathrm{Ma}$, followed by reorganization at $\sim 43$ Ma. The abandonment of spreading in the Wharton Basin and the onset of extrusion tectonics in Asia by $\sim 36 \mathrm{Ma}$ were interpreted as the likely indicators of complete continent-continent collision.

\section{Scientific Drilling in the Laxmi Basin}

A scientific drilling expedition in the eastern Arabian Sea was completed under the aegis of International Ocean Discovery Program (IODP) supported by the Ministry of Earth Sciences (MoES-India). The two months long expedition-355 was completed with participation of 30 international scientists onboard JOIDES RESOLUTION including 11 Indian scientists from various disciplines. The expedition drilled two sites of more than $1100 \mathrm{~m}$ below seafloor in the Laxmi Basin, Arabian Sea with two fold scientific objectives -1 ) to decipher the long term link between Himalayan and Tibetan Orogeny and variability of Asian Monsoon; and 2) to decipher nature of crust in the Laxmi Basin. More than 1700m long sediment and basement cores from these sites were collected. For the first time, igneous basement was cored in the Laxmi Basin which would enable scientists 
to improve existing models of paleogeographic reconstructions for the Arabian Sea in near future.

\section{Plate Boundary (Along Carlsberg-Central Indian Ridge System and within Back-arc Basin) Processes}

Generation of new crust at the mid-ocean ridges and the consumption or recycling of the older crust at the subduction zones are important processes that take place continually at the plate boundaries. The emplacement, accretion and modulation of the newly formed crust at the mid-ocean ridges due to the upcoming magma and the recycling of the older crust at the subduction zones that feed the back arc spreading centers promoting the formation of marginal seas are the processes that shape the evolution of our planet. Therefore, studies were initiated on midocean ridge and back-arc basin systems to understand the geological processes that have profound implications on the geodynamics of the Indian Ocean.

\section{Carlsberg and Central Indian Ridge System}

Multidisciplinary studies conducted over the Carlsberg and Central Indian Ridges have resulted in the mapping of finer scale segmentation pattern and helped in delineating the zones of magmatic and sparsely magmatic sections of the ridge. Extensive studies carried out over the Carlsberg Ridge covered a 600 $\mathrm{km}$ long segment, the spreading rates determined from seafloor spreading model studies of the magnetic data varied from 22 to $32 \mathrm{~mm} / \mathrm{yr}$. The water column and deep-tow investigations carried out over the mapped region of the ridge provided evidence for a prominent plume signature emanating from a seafloor hydrothermal vent system. A $700 \mathrm{~km}$ long segment of the Central Indian Ridge between $3^{\circ} \mathrm{S}$ and $11^{\circ} \mathrm{S}$ has been investigated with multibeam bathymetry, gravity and magnetics. These studies covering the youngest ocean floor (up to $4 \mathrm{Ma}$ ) along the ridge suggested a full spreading rate of 26 to $38 \mathrm{~mm} / \mathrm{yr}$. Twelve segments have been identified that divide the ridge in to magmatic and less magmatic segments. Anomalous seafloor topography was observed on NE flank of the ridge, suggesting that this is due to the gradual and progressive influence of the $\mathrm{N}-\mathrm{S}$ divergence component of the distributed diffuse plate boundary between the Indian - Capricorn plates. Prominent ridge transform intersection highs and three oceanic core complexes/ megamullion structures have been identified along the Central Indian Ridge.

\section{Andaman Back Arc Basin}

The Indo-Burmese range and the Andaman arc system in the northeast Indian Ocean define a zone of under thrusting of the Indian plate below the Southeast Asian plate, leading to the formation of a major island arc-trench system. The Andaman island arc including the Andaman and Nicobar islands together with the Andaman back-arc basin is a part of this major arc-trench system. The complexity of this tectonic province results from various factors such as the oblique subduction, arc volcanism and backarc spreading center. It has been suggested that true seafloor spreading in the back-arc basin commenced at about $4 \mathrm{Ma}$. Analysis of sediment and rock samples in the vicinity of the active spreading center and cratered seamounts suggest hydrothermal activity in the region.

The 2004 Dec 26, Mw 9.1 Sumatra Andaman Earthquake is one of the recent high intensity mega thrust earthquake occurred here. This event has caused immense loss of life in the zone influenced by the tsunami that originated in the Andaman Sea. The Andaman-Sumatra mega thrust event lead to many studies that enhanced the understanding about the mega thrust earthquakes. The other interesting feature of this region is the frequent occurrence of earthquake swarms. The January 2005 off Nicobar earthquake swarm has been related to the aftershock of the 2004 mega thrust event. Tectonic and magmatic processes associated with back arc extension were imaged by teleseismic double-difference earthquake relocation study. These studies suggested that the back-arc spreading center geometry is undergoing re-adjustment to be in equilibrium with the current plate motion demands. Recently during 2013-14 a passive Ocean bottom seismometer (OBS) experiment has been carried out in the Andaman Sea. Twelve broadband OBS units have been deployed in the back arc basin and were recovered after four months. These units have recorded several events that include teleseismic events, local events and microseismic events, the data is under analysis. 


\section{References}

Andrade V and K Rajendran (2014) The April 2012 Indian Ocean earthquakes: Seismotectonic context and implications for their mechanisms Tectnophys 617 126-139

Anitha G, M V Ramana, T Ramprasad, P Dewangan and M Anuradha (2014) Shallow geological environment of Krishna-Godavari offshore, eastern continental margin of India as inferred from the interpretation of high resolution sparker data J Earth Syst Sci 123 329-342 doi:10.1007/ s12040-013-0399-3

Arora K, V M Tiwari, B Singh, D C Mishra and I Grevemeyer (2012) Three dimensional lithospheric structure of the western continental margin of India constrained from gravity modelling: implication for tectonic evolution Geophys J Int 190 131-150

Bhattacharya G C and V Yatheesh (2015) Plate-tectonic evolution of the deep ocean basins adjoining the western continental margin of India - a proposed model for the early opening scenario, In: Mukherjee S (Ed.) Petroleum Geoscience: Indian Contexts Springer 1-61

Bhattacharyya R and T J Majumdar (2013) Basin and sub-basin crustal structure of a part of the western offshore, India $J$ Ind Geophys Union 17 179-186

Bhattacharya S N, S Mitra and G Suresh (2013) The shear wave velocity of the upper mantle beneath the Bay of Bengal, Northeast Indian Ocean from interstation phase velocities of surface waves Geophys J Int 193 1506-1514

Choudhuri M, M Nemèok, C Stuart, C Welker, S T Sinha and D Bird (2014) $85^{\circ} \mathrm{E}$ Ridge, India - constraints on its development and architecture J Geol Soc India 84513 530

Deonath A and B Mukhopadhyay (2013) A Panoptic View of Western Margin of Sundaland: Causes of Seismic Vulnerability of Sumatra J Geol Soc Ind 81 637-646

Dewangan P, N Basavaiah, F K Badesab, A Usapkar, A Mazumdar, R Joshi and T Ramprasad (2013) Diagenesis of magnetic minerals in a gas hydrate/cold seep environment off the Krishna-Godavari basin, Bay of Bengal Mar Geol 340 5770

Dewangan P, R Mandal, P Jaiswal, T Ramprasad and G Sriram (2014). Estimation of seismic attenuation of gas hydrate bearing sediments from multi-channel seismic data: A case study from Krishna-Godavari offshore basin Mar Pet Geol 58 356-367 doi:10.1016/j.marpetgeo.2014.05.015

Desa M, M V Ramana, T Ramprasad, M Anuradha, M V Lall and B J P Kumar (2013) Geophysical signatures over and around the northern segment of the $85^{\circ} \mathrm{E}$ Ridge, Mahanadi offshore, Eastern Continental Margin of India and their tectonic implications J Asian Earth Sci 73 460-472

Diehl T., F Waldhauser, J R Cochran, K A Kamesh Raju, L Seeber, D Schaff and E R Engdahl (2013) Back-arc extension in the Andaman Sea: Tectonic and magmatic processes imaged by high-precision teleseismic double-difference earthquake relocation J Geophys Res 118 2206-2224

Gibbons A D, S Zahirovic, R D Müller, J M Whittaker and V Yatheesh (2015) A tectonic model reconciling evidence for the collisions between India, Eurasia and intra-oceanic arcs of the central-eastern Tethys Gondwana Research 28 451492

Gireesh R and D K Pandey (2014) Basement characteristics along South West Indian Margin Petroleum Exploration and Development 41 68-73

Hein J R, T Conrad, K Mizell, V K Banakar, F A Frey and W W Sager (2016) Controls on ferromanganese crust composition and reconnaissance resource potential, Ninetyeast Ridge, Indian Ocean Deep Sea Res 110 1-19

Honey A (2015) Geophysical studies of the northeastern Indian Ocean with special emphasis to the evolution of the Ninetyeast Ridge thesis submitted to Goa University pp. $1-183$ (in review)

Ismaiel M (2016) Rift structure and evolution of the Eastern Continental Margin of India (ECMI) - crustal accretion and sediment deposition pattern in the Bay of Bengal, thesis submitted to Academy of Scientific and Innovative Research (AcSIR), pp 1-265 (in review)

Ismaiel M, K S Krishna, K Srinivas, J Mishra and D Saha (2016) Internal structure of the $85^{\circ} \mathrm{E}$ Ridge, Bay of Bengal: Evidence for multiphase submarine volcanism Marine and Petroleum Geology (in review)

Iyer S D, P Das, N G Kalangutkar and C M Mehta (2012) Seamounts - windows of opportunities and the Indian scenario Current Science 102 1382-1391

Iyer S D, C M Mehta, P Das and N G Kalangutkar (2012) Seamounts - characteristics, formation, mineral deposits and biodiversity Geol Acta 10 295-308

Jacob J, J Dyment and V Yatheesh (2014) Revisiting the structure, age and evolution of the Wharton Basin to better understand subduction under Indonesia J Geophys Res 119 169-190

Jaiswal P, S Al-Bulushi and P Dewangan (2014) Logging-whiledrilling and wireline velocities/ : Site NGHP-01-10, Krishna-Godavari Basin, India Mar Pet Geol 58 331-338 doi:10.1016/j.marpetgeo.2014.05.006

Jaiswal P, P Dewangan, T Ramprasad and C Zelt (2012) Seismic characterization of hydrates in faulted, fine-grained 
sediments of Krishna-Godavari basin: Unified imaging $J$ Geophys Res 117 B04306. doi:10.1029/2011JB009024

Jaiswal P, P Dewangan, T Ramprasad and C Zelt (2012) Seismic characterization of hydrates in faulted, fine-grained sediments of Krishna-Godavari Basin: Full waveform inversion J Geophys Res 117 B10305. doi:10.1029/ 2012JB009201

Kalra R, G S Rao, R Fainstein, M Radhakrishna, R Bastia and S Chandrashekar (2014) Crustal architecture and tectonomagmatic history of the western offshore of India: Implications on deepwater sub-basalt hydrocarbon exploration J Petro Sci Engg 122 149-158

Kamesh Raju KA, K Samudrala, R K Drolia, ADileep, R Ratheesh and A V Mudholkar (2012) Morphotectonic elements of the Central Indian Ridge between $3^{\circ} \mathrm{S}$ and $11^{\circ} \mathrm{S}$, Indian Ocean Tectonophysics 554-557 114-126. DOI:10.1016/ j.tecto.2012.06.001

Kamesh Raju, K A, D Ray, A V Mudholkar, G P S Murty, V K Gahalaut, K Samudrala, A L Paropkari, R Ramachandran and L Surya Prakash (2012) Tectonic and volcanic implications of a cratered seamount off Nicobar Island, Andaman Sea J Asian Earth Sci 56 42-53

Kamesh Raju KA, A V Mudholkar and K Samudrala (2015) Slow spreading ridges of the Indian Ocean: An overview of marine geophysical investigations J Indian Geophys Union 19 137-159

Khogenkumar S, A K Singh, R K B Singh, P P Khanna, N I Singh and W I Singh (2016) Coexistence of MORB and OIBtype mafic volcanics in the Manipur Ophiolite Complex, Indo-Myanmar Orogenic Belt, northeast India: Implication for heterogeneous mantle source at the spreading zone $J$ Asian Earth Sci 116 42-58

Kocherla M, B M A Teichert, S Pillai, M Satyanarayanan, P B Ramamurty, D J Patil and A Narsing Rao (2015) Formation of methane-related authigenic carbonates in a highly dynamic biogeochemical system in the Krishna-Godavari Basin, Bay of Bengal Mar Petro Geol 64 324-333

Krishna K S, H Abraham, W W Sager, M Pringle, F A Frey, D Gopala Rao and O V Levchenko (2012) Tectonics of the Ninetyeast Ridge derived from spreading records in adjacent oceanic basins and age constraints of the ridge J Geophys Res 117 B04101, doi:10.1029/2011JB008805

Krishna K S, J M Bull, O Ishizuka, R A Scrutton, S Jaisankar and V K Banakar (2014) Growth of the Afanasy Nikitin seamount and its relationship with the $85^{\circ} \mathrm{E}$ Ridge, northeastern Indian Ocean J Earth System Science 12333 47

Krishna K S (2014) Two decades of Indian research on Ninetyeast
Ridge reveal how seafloor spreading and mantle plume activities have shaped the eastern Indian Ocean Current Science 106 1178-1179

Krishna K S, K Srinivas, M Ismaiel, Y Suresh, P Sarita, D Gopala Rao, J Mishra, D Saha, S S Bhagwani and D K Srivastava (2014) Structural Style and Tectonic Evolution of Bay of Bengal from Eastern Continental Margin of India (ECMI) to Andaman with Special Reference to Hydrocarbon Prospectivity Technical Report submitted to KDMIPE, ONGC, pp 1-289

Krishna K S, M Ismaiel, K Srinivas, D Gopala Rao, J Mishra and D Saha (2016) Sediment pathways and emergence of Himalayan source material to the Bay of Bengal Current Science $110363-372$

Kundu B, D Legrand, K Gahalaut, V K Gahalaut, P Mahesh, KA Kamesh Raju, J K Catherine, A Ambikapthy and R K Chadha (2012) The 2005 volcano-tectonic earthquake swarm in the Andaman Sea: Triggered by the 2004 great Sumatra-Andaman earthquake Tectonics 31 TC5009, 11 $\mathrm{pp}$

Mallick R and K Rajendran (2016) The $2014 M_{\mathrm{w}} 6.1$ Bay of Bengal, Indian Ocean, Earthquake: A Possible Association with the $85^{\circ}$ E Ridge Bull Seismol Soc Am doi: 10.1785/ 0120150308

Mandal R, P Dewangan, T Ramprasad, B J P Kumar and K Vishwanath (2014) Effect of thermal non-equilibrium, seafloor topography and fluid advection on BSR-derived geothermal gradient Mar Pet Geol 58368-381 doi:10.1016/ j.marpetgeo.2014.04.002

Mazumdar A, H M João, A Peketi, P Dewangan, M Kocherla, R K Joshi and T Ramprasad (2012) Geochemical and geological constraints on the composition of marine sediment pore fluid: Possible link to gas hydrate deposits Mar Petro Geol 38 35-52

Mazumdar A, M Kocherla, M A Carvalho, A Peketi, R K Joshi, P Mahalaxmi, H M Joao and R Jisha (2015) Geochemical characterization of the Krishna-Godavari and Mahanadi offshore basin (Bay of Bengal) sediments: A comparative study of provenance Mar Petro Geol 60 18-33

Michael L and K S Krishna (2011) Dating of the $85^{\circ}$ E Ridge (northeastern Indian Ocean) using marine magnetic anomalies Current Science 100 1314-1322

Michael L (2012) Marine geophysical studies of conjugate regions of Bay of Bengal and Enderby Basin - breakup and evolution of structures on eastern continental margin of India PhD thesis submitted to Goa University pp 1-199

Mishra D C (2014) Geoid low and highs of the Indian Ocean and Western Pacific: Implications to mantle convections 
Journal of Asian earth Sciences 79 441-445

Mishra D C and Kumar M R (2012) Long and short wavelengths of Indian Ocean geoid and gravity lows: mid-to-upper mantle sources, rapid drift and seismicity of Kachchh and Shillong plateau India J Asian Earth Sci 60 212-224

Mishra Ravi, Pandey D K and Prerna R (2015) Active channel systems in the middle Indus fan: results from highresolution bathymetry surveys Current Science 108 409412

Misra A A, G Bhattacharya, S Mukherjee and N Bose (2014) Near N-S paleo extension in the western Deccan region, India: Does it link strike slip tectonics with IndiaSeychelles rifting? Int J Earth Sci DOI 10.1007/s00531014-1021-x

Misra AA, N Sinha and S Mukherjee (2015) Repeat ridge jumps and microcontinent separation: insights from NE Arabian Sea Mar Petro Geol 59 406-428

Mukhopadhyay R, S M Karisiddaih and A K Ghosh (2012) Geodynamics of the amirante ridge and trench complex, Western Indian Ocean Geol Rev 54 81-92

Müller R D, V Yatheesh and M Shuhail (2015) The tectonic stress field evolution of India since the Oligocene Gondwana Research 28 612-624

Murthy K S R, A S Subrahmanyam and V Subrahmanyam (2012) Tectonics of the Eastern Continental Margin of India, Book published by The Energy Resource Institute (TERI) 1-183

Nair N, S P Anand and M Rajaram (2013) Tectonic framework of Laccadive Ridge in Western Continental Margin of India Marine Geology 346 79-90

Nair N, S P Anand, M Rajaram, P R Rao (2015) A relook into the crustal architecture of Laxmi Ridge, northeastern Arabian Sea from geopotential data J Earth Sys Sci 124 613-630

Narayan S, S D Sahoo, S K Pal, U Kumar, V K Pathak, T J Majumdar and AChouhan (2016) Delineation of structural features over a part of the Bay of Bengal using total and balanced horizontal derivative techniques Geocarta Int DOI: 10.1080/10106049.2016.1140823

Nemèok M, S T Sinha, C J Stuart, C Welker, M Choudhuri, S P Sharma, A A Misra, N Sinha and S Venkatraman (2013) East Indian margin evolution and crustal architecture: integration of deep reflection seismic interpretation and gravity modeling The Geol Soc Sp Pub 369 477-496

B Padma Rao and M Ravi Kumar (2014) Seismic evidence for slab graveyards atop the Core Mantle Boundary beneath the Indian Ocean Geoid Low Physics of the Earth and Planetary Interiors 236 52-59

Pandey D K, Clift P D, Kulhanek D K, Expedition 355 Scientist
(2015) Expedition 355 Preliminary Report: Arabian Sea Monsoon International Ocean Discovery Program http:/ /dx.doi.org10.2204/iodp.pr.355.2015

Pandey A, D K Pandey (2016) Mechanism of crustal extension in the Laxmi Basin, Arabian Sea Geodesy and Geodynamics 6 409-422

Pandey D K, P D Clift IODP 355 Expedition Members (2015) Deep sea drilling in the Arabian Sea: Constraining tectonicmonsoon interactions in South Asia (Report), Expedition 355 Preliminary Report: Arabian Sea Mon-soon, International Ocean Discovery Program http://dx.doi.org/ 10.14379/iodp.pr.355.2015

Prasada Rao P, S Rajput, B Ashalatha, U Shankar, K Sain, M S Naidu, V Triveni and N K Thakur (2012) Lithospheric Structure Model of Central Indian Ocean Basin Using Ocean Bottom Seismometer Data J Earth Sci Engg 2 344359

Prerna R, Pandey D K and Mishra R (2015) Approximation of flow patterns for submarine channel systems in the Arabian Sea using a GIS approach International Journal of Advanced Remote Sensing and GIS, Cloud Publications 4 1142-1160

Radhakrishna M, G S Rao, S Nayak, R Bastia and D Twinkle (2012) Early Cretaceous fracture zones in the Bay of Bengal and their tectonic implications: Constraints from multi-channel seismic reflection and potential field data Tectonophysics $\mathbf{5 2 2}$ 187-197

Radhakrishna M, D Twinkle, S Nayak, R Bastia and G S Rao (2012) Crustal structure and rift architecture across the Krishna-Godavari basin in the central Eastern Continental Margin of India based on analysis of gravity and seismic data Mar Pet Geol 37 129-146

Rajesh S and T J Majumdar (2014) Effects of Ninetyeast Ridge magmatism and pre India-Eurasia collision dynamics on basement and crust-lithospheric structures of the northeastern Indian Ocean J Geol Soc India 84 531-543

Rajesh S, T J Majumdar and K S Krishna (2015) Lithospheric stretching and the long wavelength free-air gravity anomaly of the Eastern Continental Margin of India and the $85^{\circ} \mathrm{E}$ Ridge, Bay of Bengal Ind J Geo-Mar Sci 44 1-12

Rajesh S and T J Majumdar (2015) Satellite-derived geoid for the estimation of lithospheric cooling and basal heat flux anomalies over the northern Indian Ocean lithosphere $J$ Earth Sys Sci 124 1677-1691

Rai A K, S Tripathy and S C Sahu (2015) The May 21st, 2014 Bay of Bengal earthquake: implications for intraplate stress regime Current Science 108 1706-1712

Ramana M V, G Anitha, M Desa, T Ramprasad and P Dewangan (2014) Synthesis of deep multichannel seismic and high 
resolution sparker data: Implications for the geological environment of the offshore portion of the KrishnaGodavari Basin, Eastern Continental Margin of India Mar Pet Geol 58 339-355 doi: 10.1016/j.marpetgeo.2014. 08.006.

Ramana M V, M Desa and T Ramprasad (2015) Re-examination of geophysical data off Northwest India: Implications to the Late Cretaceous plate tectonics between India and Africa Mar Geol 365 36-51

Rao G S and Radhakrishna M (2014) Crustal structure and nature of emplacement of the $85^{\circ} \mathrm{E}$ Ridge in the Mahanadi offshore based on constrained potential field modeling: Implications for intraplate plume emplaced volcanism Journal of Asian Earth Sciences 85 80-96

Rao G S, M Radhakrishna and K S R Murthy (2015) A seismotectonic study of the 21 May 2014 Bay of Bengal intraplate earthquake: evidence of onshore-offshore tectonic linkage and fracture zone reactivation in the northern Bay of Bengal Nat Hazards DOI 10.1007/s11069-015-1750-6

Rao G S, M Radhakrishna, K M Sreejith, K S Krishna and J M Bull (2016) Lithosphere Structure and upper mantle characteristics below the Bay of Bengal Geophys J Int (in press)

Ratheesh Kumar R T, B F Windley, V J Rajesh and M Santosh (2013) Elastic thickness structure of the Andaman subduction zone: implications for convergence of the Ninetyeast Ridge $J$ Asian Earth Science 78 291-300

Ratheesh Kumar R T and B F Windley (2013) Spatial variations of effective elastic thickness over the Ninetyeast Ridge and implications for its structure and tectonic evolution Tectonophysics 608 847-856

Ratheesh Kumar R T, C I Kumar, B F Windley, T Razakamanana, R R Nair and K Sajeev (2015) India-Madagascar paleo-fit based on flexural isostasy of their rifted margins Gondwana Res 28 581-600

Ray D, K A Kamesh Raju, E T Baker, A S Rao, A V Mudholkar, J E Lupton, L Surya Prakash, R B Gawas and T Vijaya Kumar (2012) Hydrothermal plumes over the Carlsberg Ridge, Indian Ocean Geochem Geophys Geosyst Q01009 $15 \mathrm{pp}$

Sager W W, J M Bull and K S Krishna (2013) Active faulting along the Ninetyeast Ridge - implications for IndoAustralian plate break-up in the Indian Ocean J Geophys Res 118 4648-4668, doi:10.1002/jgrb.50319

Shankar U, K Sain and M Riedel (2012) Geothermal Modeling for the Base of Gas Hydrate Stability Zone and Saturation of Gas Hydrate in the Krishna-Godavari Basin, Eastern Indian Margin J Geol Soc Ind 79 199-209
Sreejith K M (2011) Geophysical studies of aseismic ridges in northern Indian Ocean - Crustal structure and isostatic models PhD thesis submitted to Goa University pp 1-182

Sreejith K M, S Rajesh, T J Majumdar, G Srinivasa Rao, M Radhakrishna, K S Krishna and A S Rajawat (2013) Highresolution residual geoid and gravity anomaly data of the northern Indian Ocean - an input to geological understanding J Asian Earth Sci 62 616-626

Sreejith K M and K S Krishna (2013) Spatial Variations in Isostatic Compensation Mechanisms of the Ninetyeast Ridge and their Tectonic Significance J Geophys Res $1185165-5184$, doi:10.1002/jgrb.50383

Sreejith K M and K S Krishna (2015) Magma production rate along the Ninetyeast Ridge and its relationship to Indian plate motion and Kerguelen hot spot activity Geophys Res Lett 42 doi: 10.1002/2014GL062993

Surya Prakash L, D Ray, A L Paropkari, A V Mudholkar, M Satyanarayanan, B Sreenivas, D Chandrasekharam, D Kota, K A Kamesh Raju, S Kaisary, V Balaram and T Gurav (2012) Distribution of REEs and yttrium among major geochemical phases of marine Fe-Mn-oxides: Comparative study between hydrogenous and hydrothermal deposits Chem Geol 312-313 127-137

Shirdkar P V, R Banerjee and Y K Xiao (2014) A revisit to Vityaz fault area, Central Indian Ridge: Isotopoic evidence of probable hydrothermal activity J Geophys Remote Sens $\mathbf{3}$ 7p doi:10.4172/2169-0049.1000125

Sriram G, P Dewangan and T Ramprasad (2014) Modified effective medium model for gas hydrate bearing, claydominated sediments in the Krishna-Godavari Basin Mar Pet Geol 58 321-330. doi:10.1016/j.marpetgeo.2014.01. 005

Sriram G, P Dewangan, T Ramprasad and P Rama Rao (2013) Anisotropic amplitude variation of the bottom-simulating reflector beneath fracture-filled gas hydrate deposit, $J$. Geophys. Res., 118, 2258-2274. doi:10.1002/jgrb.50176.

Twinkle D, G S Rao, M Radhakrishna and K S R Murthy (2016) Crustal structure and rift tectonics across the CauveryPalar basin, Eastern Continental Margin of India based on seismic and potential field modelling J Ear Sys Sci 125 329-342

Usapkar A, P Dewangan, M Kocherla, T Ramprasad, A Mazumdar and M V Ramana (2014) Enhanced methane flux event and sediment dispersal pattern in the Krishna-Godavari offshore basin: Evidences from rock magnetic techniques Mar Petro Geol 58 461-475

Usapkar A, P Dewangan, F K Badesab, A Mazumdar, T Ramprasad, K S Krishna and N Basavaiah (2016) High 
resolution Holocene paleomagnetic secular variation records from Bay of Bengal Phys Earth Planet Int 252 49-76

Valdiya K S (2015) Ocean around peninsular India Soc Earth Scientists Series 859-888

Yatheesh V, P John Kurian, G C Bhattacharya and S Rajan (2013) Morphotectonic architecture of an India-Madagascar breakup related anomalous submarine terrace complex on the southwest continental margin of India Mar Petro Geol 46 304-318
Yatheesh V, J Dyment, G C Bhattacharya and R D Müller (2013) Deciphering detailed plate kinematics of the Indian Ocean and developing a unified model for east Gondwanaland reconstruction: An Indian-Australian-French initiative DCS Newsletter 23 2-9. 